\title{
A Study on Chinese Shape Taking Methods Reflected on the Character Making Process: Focusing on Major Nature Gods
}

\author{
Changjoon YOON (Corresponding author) \\ Dept. of Chinese Studies, Keimyung University \\ PO Box 42601, Deagu, Dalgubeoldaelo \#1095, Korea \\ Tel: 82-53-580-5153 E-mail: cjyoonh@kmu.ac.kr
}

Received: May 25, 2020 Accepted: June 18, 2020 Published: June 19, 2020

doi:10.5296/ijch.v7i1.17088 URL: https://doi.org/10.5296/ijch.v7i1.17088

\begin{abstract}
'Letters record a language' means that letters, in specific forms, represent particular meaning and sounds differentiated from others. Because one language reflects its people's way of thinking, letters also include those thinking as a sign of that language. Especially from the very beginning, Chinese characters were devised to take the shapes that represent meaning of languages rather than the signals that indicate pronunciation, therefore the shapes of Chinese characters, especially that of the ancient pictographs, can be treated directly as very precious historical data, also can be said exactly reflect social aspects of the times.

But in some cases, meaning of language did not have specific shapes that represent exact meaning, so people in Shang Dynasty have to develop the system of taking shapes that represent abstract meaning.

To search for this, this research made consideration on the taking shapes system of Chinese character based on the findings through the analysis of oracle-bones letters and oracle-bone inscriptions regarding The God of Nature, especially The God of dragon, wind, rainbow, sun.
\end{abstract}

Keywords: Oracle-bones letters, Oracle-bone inscriptions, Taking shapes system of Chinese character, The God of Nature

\section{Introduction}

The purpose of this study is to analyze and consider concrete example characters and oracle-bone inscriptions to figure out how the shapes of concepts were taken to make the 


\section{Ml Macrothink}

shapes of Chinese characters in cases where there was no concrete object that objectively existed when Chinese were initially making Chinese characters and in what meanings the Chinese characters were employed after being made.

That is, since Chinese characters were not made as signs that indicate the pronunciations of the language but were made as shapes that represent the meanings of the language from the beginning, the shapes of ancient Chinese characters relatively clearly reflect the shapes that represent the meanings of the language at the time of making the characters. Below are several examples.

\begin{tabular}{|c|c|c|c|c|c|c|c|}
\hline Square style & 馬 & 鹿 & 犬 & 豕 & 羊 & 牛 & 象 \\
\hline $\begin{array}{l}\text { Oracle-bone } \\
\text { character }\end{array}$ & 受 & 黨常 & f & t女 & $\dddot{Y}$ & $\psi$ & f \\
\hline Source & 『京』1681 & 『合集』19956 & 『乙』2639 & 『合集』33365 & 『前』4.50.4 & 『甲』202 & 『前』3.31.3 \\
\hline
\end{tabular}

The characters '馬(horse)', ‘鹿(deer)', ‘犬(dog)', ‘豕(pig)', ‘象(elephant)' were made by modeling after the entire shapes of the objects of the characters while effectively highlighting the characteristics of the objects such as the mane of horses, the antler of deer, the long and curved tail of dogs, the ample belly and short legs of pigs, and the long trunk of elephants, and the characters '羊(sheep)' and '牛(cattle)' were made by taking the shapes of horns, which are the most characteristic parts, instead of the entire shapes of the objects. Since the characters were made by taking the shapes of the objects as they were in all cases where there were objectively existing shapes of the objects as such, the relationships between the shapes and meanings of characters are quite direct.

\begin{tabular}{|l|l|l|l|l|}
\hline Square style & 占 & 西 & 㣎 & 照 \\
\hline Oracle-bone character & 台 & 夏 & 本 & 第 \\
\hline Source & 『乙 6901 & 『甲』86 & 『南明』625 & 『後下』7.10 \\
\hline
\end{tabular}

The character '占(liquor barrel)' was made by modeling after the shape of the barrel to contain liquor and the character '西(liquor container)' indicates the wide mouth, narrow neck, and broad body of jars. The character '鬲(pot)' was made by imitating the shape of the utensil with three feet and the character '單(wine cup)' was made by modeling after the ancient wine cup with two ears and three feet.

All of the above characters were made by modeling after the shapes of objects as they were because the objects of shape taking existed objectively and greatly help the understanding of ancient China today. That is, since the shapes of these characters are directly related to the meanings of the characters and the shapes contained in the characters are clear, the characters 
become the grounds for the estimation of the origins and uses of the excavated bronze ware and are helpful to the analysis of the kinds and uses of weapons manufactured in the Shang Dynasty period.

However, since the concrete objects from which shapes could be taken did not objectively existed for all letters, it should have been difficult to determine how the shapes of intangible concepts with no shape should be taken to make characters and how the shapes that would determine the shapes of characters should be extracted in the case of concepts added with various mythical or legendary characteristics.

Therefore, in this study, the shapes of oracle-bone characters and oracle-bone inscriptions related to major natural gods that can reflect major characteristics of the shape taking system for Chinese characters will be analyzed to examine how ancient Chinese took the shapes of intangible concepts to make characters and the background of the principles of character making will be analyzed through concrete example characters and oracle-bone inscriptions to use the results as a cornerstone for examination of the entire thinking system of ancient Chinese. Since the structures of thinking are closely related to the characteristics of the language used by the thinkers and the structure of a language is closely related to the characteristics of the way of thinking shared by the users of the language, Chinese characters as a means of recording the language become the basis of human thinking and it can be said that Chinese characters are refined through human thinking and change through human life. Eventually, the way how shapes were taken to make characters is expected to become a major means of examination of the characteristics of the way of thinking of ancient Chinese.

To that end, in this study, oracle-bone characters and oracle-bone inscriptions, which are regarded to be the oldest Chinese characters in existence, will be analyzed not only because oracle-bone characters could avoid the deformation in the process of being handed down because they are real character data made and inscribed firsthand by people in the Shang Dynasty period but also because oracle-bone inscription data made to tell people's fortune using oracle-bone characters are handed down in large quantities and they are relatively reasonably interpreted even today when several thousand years has passed because they are the original forms of the Chinese characters that have been used until today. ${ }^{1}$

\section{The Ways How the Shapes of Major Nature Gods Were Taken}

Although ancient Chinese believed 'death' as not awakening from sleep and took care of their 'sleeping relatives', they felt infinite fear and doubt as the bodies gradually rotted over time. Based on their memories of dreams they had, they became to believe that souls could exist independently after being separated from the body and eventually became to have a notion of souls. $^{2}$

\footnotetext{
1 于省吾 said, "Among ancient Chinese ancient characters, pictograms and ideograms per se are rare and precious historical materials because they often reflect the actual situations of ancient social activities. (中國古文字中某些象形和象 意字, 往往反映了古代社會活動的實際情況, 可見文字本身也是很珍貴的史料.)” and this comment is thought to be very appropriate. (于省吾，『甲骨文字釋林』，北京，中華書局, 1979, p.5)

2 柯斯文, 『原始文化史綱』，北京，人民出版社，1955，pp.179-180
} 
Although it cannot be known exactly when the notion of souls was formed, given that red iron oxide power that symbolizes blood was scattered around the dead bodies of an old man and a female found in the historic site in a cave at a mountain top in Zhoukoudian, Beijing, it can be assumed that a notion of souls already existed at the time of Shāndǐng Dòngrén(山頂 洞人). That is, people at that time regarded that blood was necessary to souls too and buried the red iron oxide power that symbolizes blood together with dead bodies for eternal life of souls. $^{3}$

Thereafter, the notion that souls exist forever developed into a notion that not only humans but also all other things in nature have souls and this notion eventually became the basis of the worship of natural gods. That is, ancient Chinese became to sense that there were certain rules in the changes in the natural world, such as the rising and setting of the sun, the blowing of winds, and the rising of rainbows and become to believe that such changes were controlled by gods in a world invisible to humans. In the face of changes in nature, which could never be resisted by human power, ancient Chinese had a notion that all things have souls and believed that if they devotedly worshiped the gods who rule all things, they could move nature according to their will. Accordingly, many nature-related worship thoughts were made and many worship notions occurred as such lasted until the Shang Dynasty period and contents related to the worship of nature gods can be found in currently existing oracle-bone inscriptions.

Below, centering on major nature gods worshiped by ancient Chinese, the principles for making related oracle-bone characters and the meanings of the oracle-bone characters in oracle-bone inscriptions will be analyzed to examine what shape taking methods were used to make those Chinese characters that had no objectively existing concrete objects.

\subsection{Dragon God}

In oracle-bone inscriptions, 'dragon' mainly appears as an euphemism of a god or an ancestor of the Shang Dynasty. For instance, the word dragon was used as follows.

壬寅卜賓貞. 若不雨, 龍不若. 王占曰, 龍不若.( 遺 620) : On the day of Rén yín, the guest asked, 'If it does not rain, should the Dragon God permit?' The king said, 'the Dragon God did not permit.'

卜殸貞，御婦好于龍甲.(『臵』8.12) : 殸 asked, 'Will the woman perform a royal ancestral rite for dragon gab?

As shown in the above oracle-bone inscriptions, 'dragon' appeared as a nature god that is in charge of rains or was used as a euphemism of ancestors of the Shang Dynasty and was worshiped.

The oracle-bone character of '龍' was made by modeling after the long curved body and

3 宋兆麟, 『中國原始社會史』, 北京, 文物出版社, 1983, p.12 


\section{Macrothink}

beautiful scales as shown in the following table. From what was the shape of 'dragon', which existed only in imagination without actual body, taken to make the character?

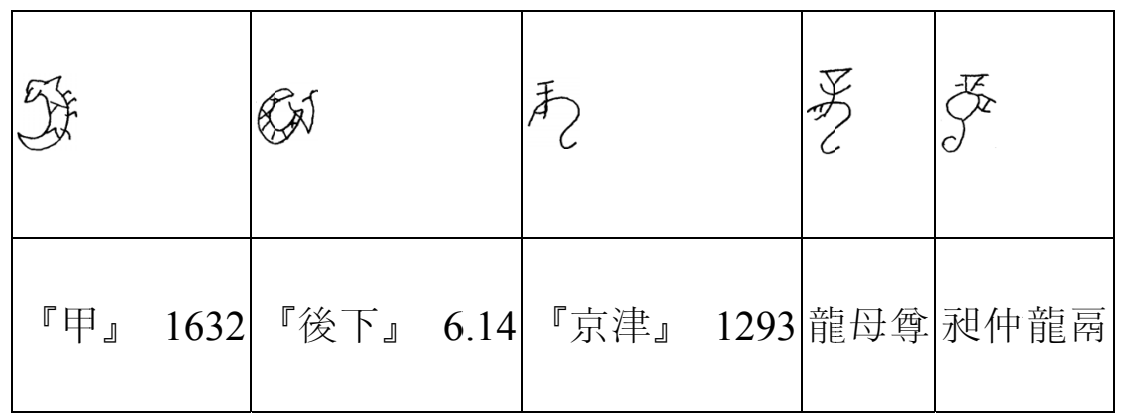

In 1987, a tomb in the early Yangshao culture, which was about 6,000 years ago, was excavated in Fuyang, Henan Province. A dragon made by piling up shells was laid on the left of the dead body of a man who was the owner of the tomb and a tiger also made by piling up shells was laid on the left of the dead body of the man. This dragon is called the "first dragon in China" in China. Also in 1984, a dragon made of black-green jade called 'The first dragon in the world' and a pig-headed jade dragon were found together in Inner Mongolia. They are estimated to have been made in the period of Liangzhu Culture, which corresponds to about 5,000 years ago from now. ${ }^{4}$

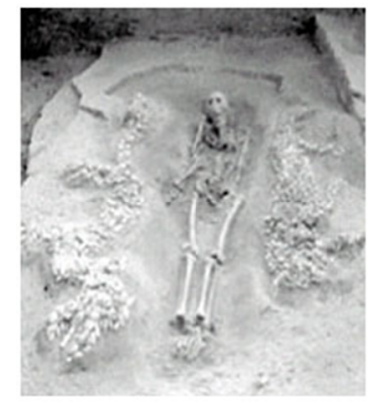

The first dragon in China(left) The first dragon in the world

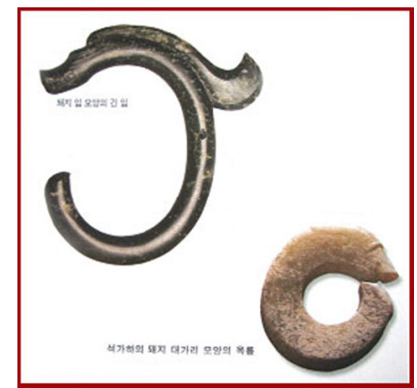

Pig-headed dragon

On comparison of the shapes of these artifacts with the shape of the oracle-bone character '龍', it can be seen that they are very similar. Given that the currently existing oracle-bone characters were made by the royal family of the Shang Dynasty in order to inscribe the contents of fortune telling after telling fortunes about daily lives of the royal family of the Shang Dynasty, which were matters of great consequences of the nation and a series of events related to the king for about 273 years after Pan Geng(盤庚) moved the capital to Yin(殷) at the end of Shang Dynasty until the Shang Dynasty was destroyed by the Zhou Dynasty, it can be said that the shape of the oracle-bone character '龍' was made by modeling after the shapes of various utensils made based on the shape of dragon in imagination, which existed only in myths.

4 韓鑒堂, 『中國文化』, 北京, 北京語言文化大學出版社, 1999, pp.62-65 


\subsection{Wind God}

The oracle-bone character '風(wind)' was made by taking the shape of the god bird wearing a crown on the head and the original meaning of this character was not 'wind' but the 'big bird' appearing in myths, that is, phoenix('鳳' ${ }^{5}$.

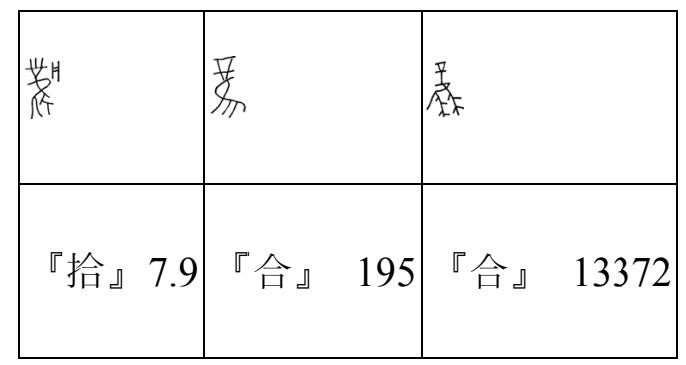

However, in oracle-bone inscriptions, the character '風' was mainly used with the meaning 'wind' instead of the original meaning 'phoenix'. Examples are as follows.

辛未卜, 貞. 今辛未大風不隹禍(『前』 8.14.1) : On the day of Xin Wei, Zhēn asked,

'Today, on the day of Xin Wei, shouldn't heavy winds blow to leading to disasters?'

丙午卜，互貞. 今日風田(『合集』13369): On the day of Bingwu, Gèn asked, 'Should winds blow today leading to disasters?

Since 'winds' were a threatening being that leads to disasters to humans as shown in the above oracle-bone inscriptions, people in the Shang Dynasty period worshiped '風(winds)' as a god and held religious services offering livestock such as sheep, pigs, and cattle as sacrifices. Examples of such oracle-bone inscriptions are as follows.

甲戌, 貞. 其寧風 ${ }^{6}$, 三羊, 三犬, 三豕( 『續』2.15.3) : On the day of Jiă xū, Zhēn asked,

'Shall we hold a stopping religious service to stop winds with three sheep, three dogs, and three pigs?

貞. 禘風三羊，三豕，三犬(『前』4.17.5)：Zhēn asked, 'Shall we hold a imperial sacrifice service for Wind God with three sheep, three pigs, and three dogs?

Oracle-bone inscriptions show many traces of attention paid to changes in wind power. For instance, ‘不風(no wind)’, “來風(coming wind)’, “風多(many winds)', “延風( successive winds)', ‘小風(small wind)', ‘大風(large wind)', ‘大風兄(elder brother of large wind)', ‘驟 風(gale)’, ‘大驟風(large gale $)^{7}$ ' were records of different strength levels of winds.

\footnotetext{
5 万述金金 外, 『甲骨金文字典』，成都，巴蜀書社，1993，p.1031

6 '寧風' means 'stop winds[止風]' and '寧' was used as the name of religious services to stop winds. 王宇信.楊升南, 『甲骨 學一百年』, 北京, 社會科學文獻出版社, 1999, p.593

7 “癸卯卜, 爭貞. 旬亡尤. 甲辰 $\square$ 大驟風. As shown in (On the day of Gul măo, Zhēng asked. 'Will there be no disaster
} 


\section{MInstitute Macrothink}

Then, why was the character made by taking the shape of the god bird wearing a crown on the head used as ‘風', which means 'winds', instead of '鳳', which means a 'bird'?.

Although previous studies have explained the foregoing as the use of another character with the same sound regardless of the meaning, why the character '鳳', which means 'god bird', was used to write the word 'wind' out of many other characters with the same sound has not been very clearly explained.

However, it can be explained on reviewing the contents related to the origin of winds out of the early wind god worship thoughts of ancient Chinese. That is, among ancient Chinese' myths and folk tales are found many that are related to the origin of winds. For instance, those that reflect the matriarchal society are found such as a myth that there is an old woman with scattered hair at the end of the world and since her hair is so long that even when she just shakes her hair, heavy winds immediately blow on the earth ${ }^{8}$, and a myth that a temptress has a sack filled with winds and when she opens the sack, large winds blow ${ }^{9}$ but those that associated the beginning of winds with birds are found frequently too. That is, those that indicate that winds are formed when big birds such as ‘鵬(feng)’ that appears in 『莊子.逍遙

遊』 flap the wings ${ }^{10}$ are found. These are the grounds the assumption that the character '鳳”,

that was made by taking the shape of god bird was used not because the pronunciation of the character '鳳' and that of the word meaning winds were the same but because the myth of ancient Chinese in which 'winds' were regarded to be formed when large birds move their wings when they fly was reflected. That is, to make a character that indicates the meaning of intangible 'wind god' that is invisible, ancient Chinese used the character '鳳' for the 'big bird', which was believed as the origin of 'winds'.

\subsection{Rainbow God(虹神)}

The oracle-bone character '虹' was made by imitating the shape of the monster that had two heads and each head had a large mouth.

\footnotetext{
for 10 days? Large gales blew on the day of Jiachen.)"(『合集』137 正)), 'large gales' are frequently shown in oracle-bone inscriptions. 葉玉森 said that the shape $\left({ }^{n}, \vec{*}, \overrightarrow{7}\right)$ of the oracle-bone character '驟' was the shape of an ax held by two hands and said, "The oracle-bone character '驟' was modeled after the axes of the heaven and the earth because thunder can kill people(蓋古代myth謂雷能殺人，乃天地之斧鐵.)”. However, 于省吾 said that the foregoing was a wild guess and explained, "The shape of the oracle-bone character '驟' was a shape of the ear held on the top and bottom and was an ancient shape of '掫' but 掫 was used as 聚 in 『說文通訓定聲』 of 朱駿聲." In addition, in 『讀書雜志』of 王念孫, there is a comment, “冣 and 驟 are the same. 冣 is the ancient shape of 聚, and 聚 was originally written as 驟." Therefore, the oracle-bone character " should be written as '驟'. The annotation of “驟雨不終日." in 『老子』 by 河上公 indicated, “驟 雨 is torrential rain." and 『一切經音義』 of 玄應 indicated, “驟 is suffering.". Therefore '大驟風' should be regarded as referring to very heavy rains. 于省吾，『甲骨文字釋林』，北京，中華書局, 1979, p.12

8 『中國各民族宗敎與神話大詞典』編審委員會編，『中國各民族宗呚與神話大詞典』，北京，學苑出版社，1990， pp.135-136

9 『中國各民族宗敎與神話大詞典』編審委員會編，『中國各民族宗呚與神話大詞典』，北京，學苑出版社，1990， p. 455

10 『中國各民族宗㸚與神話大詞典』編審委員會編, 『中國各民族宗學與神話大詞典』, 北京, 學苑出版社, 1990, p.124, 355, 401
} 


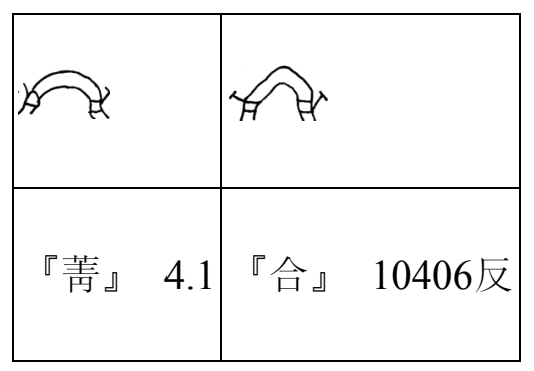

This character was mainly used for the meaning 'rainbow' in oracle-bone inscriptions. ${ }^{11}$ An example is as follows.

\section{王占曰, ... 亦有出虹自北拎于河( 葑 4): The king predicted, 'The rainbow will come}

from the north and drink water in the river.

Although the objective shape of rainbows that can be seen by the eyes is similar to the shape of the oracle-bone character, on comparison with the actual shape, it can be seen that the element 'two heads with a big mouth at both ends' was added. Then, why did ancient Chinese add the imaginary element to the actual shape of rainbows.

『山海經.海外東經』 have a description that reads, “虫而 lives in the north and it has two heads, one on each end.(虽在其北，各有兩首.)”. 12 “蝁” means 'rainbow' and is a variant form of '虹'. That is, the description is a mythic content indicating that the rainbow lives in the north and has two heads, one on each end. Since the appearance of rainbows was a very mysterious phenomenon to ancient Chinese, many myths and legends regarding rainbows were made and eventually, the identify of rainbows was defined as 'a monster with two heads living in the north. This story is found in many ancient classics including ${ }^{『}$ 山海經(Shan Hai Jing)』 .

The mythic element as such was reflected on the process of making the oracle-bone character so that the shape of two heads with a big mouth was added to the actual shape of rainbows. Oracle-bone inscriptions have records indicating that rainbows always appear in the 'north' and this can be also regarded to have reflected the mythic element related to the appearance of rainbows.

Thereafter, the body that looks like a 'snake' was represented by '虫' and the pronunciation of 'rainbow' was represented by '工' so that the shape/sound-based word '蝁' was made.

\subsection{Sun God(日神)}

The oracle-bone character for '日' was written in the shape of a round or square outline with

\footnotetext{
11 方述金金 外, 『甲骨金文字典』，成都，巴蜀書社，1993，p.1028，徐中舒，『甲骨文字典』，成都，四川書辭，第5 次印刷本, 1998, p.1426

12 郭璞 said that the consonant of “ was the same as that of '虹' and 袁珂 said that “was a variant form of '虹'의 異體字. 袁珂，『山海經校注』，成都，巴蜀書社, 1993, pp.302-303
} 
a point inside the outline and the Jin Wen for '日' was similar. Examples are as follows.

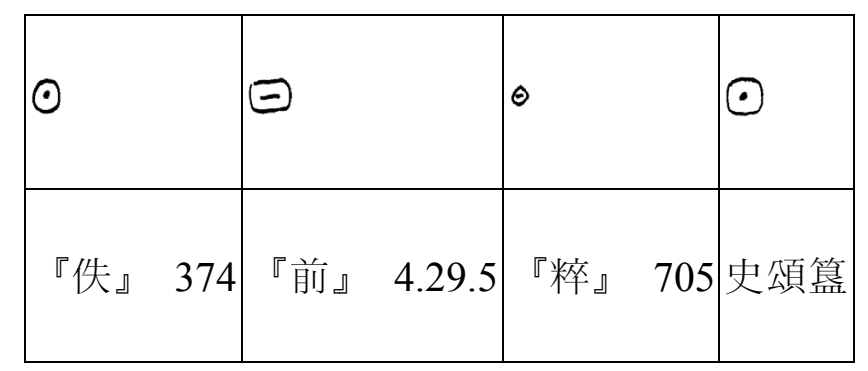

The oracle-bone character for '日' was clearly made by imitating the shape of the sun. However, there have been different opinions of many scholars about the dot marked on the center thus far but there is no established theory yet. ${ }^{13}$

To solve this problem, first, in what meaning '日' was used in oracle-bone inscriptions should be examined and in what forms the sun appears in the myths and legends of ancient Chinese should be studied thereafter.

In oracle-bone inscriptions, '日' mainly appears as a nature god, which is a subject of religious services. Examples are as follows.

壬子卜, 旅貞. 王賓日不雨( 『合集』22539) : On the day of Rén zi, Lü asked, 'If the king performs a Bīn religious service for the Sun God, will the rain stop?

貞. 于日穓 ${ }^{14}$, 王受又 ${ }^{15}$ (『合集』30987) : Zhēn asked, 'If we perform a Zhēng religious service for the Sun God, will the king be protected?

乙巳卜, 王賓日. 不賓日(『佚』 872) : On the day of Yĩ sì, Zhēn practiced divination.

Should the king perform a Bīn religious service for the Sun God or not?

As explained above, in oracle-bone inscriptions, '日(sun)' appears as a subject of religious services performed to stop rains or obtain protection.

In addition, oracle-bone inscriptions frequently shows religious services performed for '出日 (rising sun)' and '入日(setting sun)' in addition to '日(sun)'. Examples are as follows.

\footnotetext{
${ }^{13}$ For instance, there is an argument that many of oracle-bone characters were inscribed in squares because it was difficult to inscribe circles and the dot was marked on the center to distinguish the character from round or square signs and there is an argument that the dot was marked to show the shape of the sunspot. 徐中舒，『甲骨文字典』，成都，四川書辭，1998， p.719

14 趙誠(2000:51) identified this character as '蒸' and said that it was a name of religious services. In this paper, the determination in 『甲骨文合集.釋文』 is followed.

15 In oracle-bone inscriptions, '又' was used as the initial form of '右' with meanings such as '佑', '侑' and '有'. Here, it was used for the meaning of '佑' in '保佑(protect)'.
} 
辛未. 又 ${ }^{16}$ 于出日. 滋不用.(『合集』33006): On the day of Xin Wei, shall we perform Yòu religious service? It was not performed as planned.

丁巳卜, 又入日(『合集』34163)： I practiced divination on the day of Dīng sì.

'Shall we perform Yòu religious service for the setting sun?

乎雀械于出日于入日( 『乙』2063): Shall I tell Què to perform Shù xū religious service for the rising sun and the setting sun?

侑出日, 侑入日(『佚』 407) : Shall we perform Yòu religious service for the rising sun and perform Yòu religious service for the setting sun?

出入日, 歲三牛(『粹』 17) : Shall we perform Suì religious service for the rising sun and the setting sun?

王其觀出日, 其截于日(『屯南』2232): Shall the king watch sun rising and perform $\mathrm{Jie}^{17}{ }^{17}$ religious service for the Sun God?

Regarding the '出日' and '入日' in oracle-bone inscriptions, scholars have different opinions, which are divided into arguments that regard the '出日' and '入日' as the rising and setting sun per se and those that regard the '出日' and '入日' as the times of sun rising and sun setting. ${ }^{18}$ With regard to the foregoing, 宋鎭豪 analyzed a total of 23 articles of related data shown in oracle-bone inscriptions and said that although 出日 and 入日 basically meant sun rising and sun setting, respectively, they did not just mean the time points of sun rising or sun setting or sun rising or sun setting per se but they were one of unique methods of religious services implemented in the Shang Dynasty period and the religious services were performed firsthand by the king while observing sun rising and sun setting regularly at certain places at certain times such as the vernal equinox and the autumnal equinox. This explanation

\footnotetext{
${ }^{16}$ In the above oracle-bone inscriptions, ' $又$ ' was used as '侑', which is a name of religious services.

17 '截' refers to religious services for the Sun God. See 宋鐄豪(1994:469-470).

18 陳夢家 said, “It is performing religious services for the sun.(祭日之辭.)”.(“古文字中之商周祭祀”，北京，『燕京學報』 $19^{\text {th }}$ edition, 1936), 郭沫若 said, "People of the Yin Dynasty generally performed religious services for the sun in the morning and in the evening. (殷人于日盖朝夕禮拜之.)”(『殷墟粹編.考釋』, 東京, 日本東京文求堂, 1937), and 胡厚宣 said, "People of the Yin Dynasty performed religious services for the sun, in the morning and in the evening when the sun rises and sets, respectively. (殷人有祭日之禮，且于日之出入朝夕祭之.)”.(“殷代之天神崇拜”，『甲骨學商史論叢初集』 (上) 臺北，臺灣大通書局, 1944, pp.281-338) 董作賓 said “There was the sun god in the Yin Dynasty period and people performed religious services for the sun god at the times of sun rising and sun setting.(殷代有日神, 于日出日入時祭 祀.)"(“中國古代文化的認識”, 『大陸雜誌』, 第3卷 第12期, 1951, p.12), 島邦南 said that 出旧 and 大日 were words indicating times( 『殷虛oracle-bone inscriptions研究』, 弘前, 中國學研究會, 1958, p.231), and 金祥恒 said “出日 and 入 日 originally mean 日出(sun rising) and 日沒(sun setting).(出日入日本爲日出日落之意.)”.("甲骨文“出'.'日入'日說”, 『中國文字』第26冊, 臺北, 藝文印書館, 1967, p.65)
} 
is accepted as being very reasonable. ${ }^{19}$

Oracle-bone inscriptions also show records of divination practiced regarding that the phenomena of abnormal running of the sun were omens of disasters given by the Sun God. An example is as follows.

癸巳卜，爭貞. 日若兹敏, 惟年禍. 三月(『通』 448)：On the day of Guǐsì, Zhēng practiced divination to ask, 'The sun is suddenly getting dark, will there be disasters? It was in March.

The above oracle-bone inscriptions show a case where the phenomenon in which the day was suddenly getting dark was regarded as an omen of disasters that would be imposed by the sun god and divination was practiced. Oracle-bone inscriptions also show records regarding solar eclipse and lunar eclipse. Examples are as follows.

癸西貞. 日月有食, 惟若. 癸西貞. 日月有食, 非若( 『笽天』1)：On the day of Guǐ yǒu, it was asked, 'Will a solar eclipse and a lunar eclipse occur?' On the day of Guǐ yǒu, it was asked, 'Will a solar eclipse and a lunar eclipse occur?'

癸巳卜貞，今其有点。一 二告...雨...甲午暈. 三 四(『合集』 13048)：Divination

was practiced on the day of Guǐsì, 'Will a disaster occur now? ... rain... On the next day, the day of Jiǎwǔ, a solar eclipse phenomenon occurred.

The first oracle-bone inscription is a record of divination practiced about whether the phenomena of solar eclipse and lunar eclipse would occur and the oracle-bone inscription shows a record of a case where the phenomenon of solar eclipse in which the sun is completely eclipsed by the moon was judged as a disaster. ${ }^{20}$

In「交食譜.日譜」, 董作賓 said that “日月有食' referred to the solar eclipse and lunar eclipse phenomena and that the reason why such phenomena were expressed as '食' was that folk tales in which the solar eclipse and lunar eclipse phenomena were regarded to have occurred because the dog of heaven ate the sun and the moon were reflected. ${ }^{21}$

Through the above-mentioned oracle-bone inscriptions, it can be seen that people in the Shang Dynasty period regarded the sun as a nature god and performed religious services for the sun. ${ }^{22}$ In addition, whether 出日 and 入日 referred to the rising and setting sun per se

\footnotetext{
19 According to his analysis, in the Shang Dynasty period religious services were mainly performed for the rising sun and the setting sun using cattle or sheep for religious services as sacrifices. At the beginning, mainly Shù xū religious services were performed and '出日(rising sun)' and '入日(setting sun)' were separately recorded, However, in the middle and late periods, Yòu religious services and Măo religious services were performed and '出日' and '入日” were recorded as if they were one word like '出日入日' or '出入日'. 宋鍧豪, “oracle-bone character出日入日考”, 『出土文獻研究』, 北京, 文物 出版社, 1985，『夏商社會生活史』，北京，中國社會科學出版社, 1994, pp.472-473

20 嚴一萍, “殷商天文志”，『中國文字』新2期，臺北，藝文印書館，1980

21 宋鎭豪，『夏商社會生活史』，北京，中國社會科學出版社, 1994, p.469

22 In addition, some other oracle-bone characters were made by taking the shape of measuring directions and time using the
} 
or the time point of sun rising and sun setting, or a unique method of religious services implemented in the Shang Dynasty period as argued by 宋鎭豪, it is clear that sun rising and sun setting were regarded as important. Then, why did the people in the Shang Dynasty period regarded sun rising and sun setting as such?

To ancient Chinese, the sun that rose from the east and set to the east every day to give brightness and warmth was a subject of wonder and accordingly, many myths and legends wedre made by ancient people's imaginations to answer to the questions such as from where does the sun comes and who operate the sun. For instance, 『山海經』 and 『淮南子』 contain many stories related to the sun such as stories about the birth of the sun that read, "In the area between Gān shuǐ(甘水) across the southeastern sea is a nation of Xī hé(羲和). The name of a woman living there is Xī hé. Xī hé is the wife of Dì jùn(帝俊) and gave birth to ten suns.(東南海之外，甘水之間，有羲和之國，有女子名曰羲和，羲和者帝俊之妻，生十 日.)” and stories about the runing of the sun that read, “The sun always rides on a bird when it rises and sets.(日之出入, 皆載于鳥.)”。

The myths and legends as such indicate that people in the Shang Dynasty period associated the running of the sun with a big bird. That is, ancient Chinese believed that the sun running in the sky was moving on the back of a big bird and accordingly, they regarded the phenomena of sunrise and sunset as important and performed religious services for the sun. In fact, a pattern of a crow flying while carrying the sun on its back was drawn on a fragment of a painted pottery excavated in a historic site of Yangshao culture in Quán-hù Village, Hua County, Shaanxi Province. Such relics coincide with the contents of the myths and legends contained in $『$ 山海經』.

Then, what does the dot added to the center in the character '日' meaning the 'sun' symbolize? As mentioned earlier, people in the Shang Dynasty period regarded the sun as a god and performed religious service for the sun. In addition, they regarded the phenomena of sunrise and sunset as very important. Furthermore, ancient Chinese made myths and legends indicating that a big crow runs the sun from the east to the west by carrying the sun on its back.

On reviewing the relics of ancient China on which crows and the sun were drawn, it can be seen that whereas those at the beginning had patterns of a crow carrying the sun on its back as with the pottery in Quán-hù Village, Hua County, Shaanxi Province, those in the later period have patterns in which the crow is in the sun, and those in the still later period have patterns with crows symbolized into small dots.

Therefore, on putting together, the myths and legends of ancient Chinese about the sun and the records on oracle-bone inscriptions indicating that ancient Chinese performed religious

shadows of the sun. For instance, "(『合集』30365) is a shape of determining the direction by holding a column in a hand to make the shadow of the sun on the ground and "(『合集』22942) is a shape of measuring times by erecting a wooden column on the ground thereby using the shadow of the sun. These characters become good materials that enable judging the level of astronomy of people in the Shang Dynasty period. 


\section{Macrothink

services for the sun and regarded sunrise and sunset as important, it can be assumed that the small dot drawn in the oracle-bone character '日' symbolizes the big crow said to have flied carrying the sun on its back.

\section{Results}

The purpose of this study was to examine how ancient Chinese made the shapes of Chinese characters for concepts with no concrete object existing objectively and in what meanings the Chinese characters were used after being made by analyzing oracle-bone characters and oracle-bone inscriptions. To that end, in this paper, the principles under which each of the characters for major nature gods such as 龍(dragon), 風(wind), 虹(rainbow), and 日神(sun god) appearing in the currently existing oracle-bone characters and oracle-bone inscriptions were made and in what meanings the characters were used in oracle-bone inscriptions were examined.

\subsection{Reflecting Fictional Images Made through Imagination}

Through the analysis mentioned above, it could be seen that first, when making the character for 'dragon'(龍) of which the actual body did not exist, ancient Chinese imitated the shapes of various utensils reflecting fictional images made through imagination.

\subsection{Reflecting the Mythic and Legendary Elements Related to the Origin of Winds}

It could be seen that in the case of natural phenomena that are not visible but can be felt through senses such as 'wind(風)', instead of making new characters, the character '鳳', which means 'big bird' was used reflecting the mythic and legendary elements related to the origin of winds.

\subsection{Various Mythic Elements Were Added to Make the Character}

Even in cases where visible objects exist as with the 'sun(日)', the actual shape of the sun was not taken as it is but various mythic elements related to the running of the sun were added to make the character.

\subsection{Various Mythic Elements Were Added to Make the Character}

In the case of 'rainbow(虹)', as with the 'sun', the shape of the visible objective object was not taken as it is but various mythic elements related to rainbows were added to make the character.

\section{References}

『中國各民族宗敎與神話大詞典』編審委員會編，『中國各民族宗敎與神話大詞典』，北 京，學苑出版社, 1990

陳夢家, “古文字中之商周祭祀”, 北京，『燕京學報』 $19^{\text {th }}$ edition, 1936 
崔恒昇，『簡明甲骨文詞典』，合肥，安徽敎育出版社，1986

島邦南，『殷虛卜辭研究』，弘前，中國學研究會，1958

董作賓, “中國古代文化的認識”, 『大陸雜誌』，第 3 卷 第 12 期, 1951

方述金外，『甲骨金文字典』，成都，巴蜀書社, 1993

郭沫若，『殷墟粹編.考釋』，東京，日本東京文求堂，1937

韓鑒堂，『中國文化』，北京，北京語言文化大學出版社, 1999

胡厚宣, “殷代之天神崇拜”、『骨學商史論叢初集』(上) 臺北，臺灣大通書局, 1944

金祥恒，“甲骨文“出’‘日入’日說”，『中國文字』第 26 冊，臺北，藝文印書館, 1967

柯斯文，『原始文化史綱』，北京，人民出版社，1955

宋兆麟，『中國原始社會史』，北京，文物出版社，1983

宋鎭豪, “甲骨文出日入日考”, 『出土文獻研究』，北京，文物出版社，1985

宋鎮豪，『夏商社會生活史』，北京，中國社會科學出版社, 1994

王宇信.楊升南，『甲骨學一百年』，北京，社會科學文獻出版社，1999

徐中舒，『甲骨文字典』，成都:四川書辭，第 5 次印刷本, 1998

嚴一萍，「殷商天文志」，『中國文字』新 2 期, 臺北, 藝文印書館, 1980

于省吾，『甲骨文字釋林』，北京，中華書局, 1979

袁珂，『山海經校注』，成都，巴蜀書社, 1993 
趙誠，『甲骨文與商代文化』，沈陽，遼寧人民出版社，2000

\section{Copyright Disclaimer}

Copyright reserved by the author(s).

This article is an open-access article distributed under the terms and conditions of the Creative Commons Attribution license (http://creativecommons.org/licenses/by/3.0/). 